University of Puget Sound

Sound Ideas

All Faculty Scholarship

Faculty Scholarship

$1-1-2007$

\title{
Augustan Religion And The Reshaping Of Roman Memory
}

Eric M. Orlin

University of Puget Sound, eorlin@pugetsound.edu

Follow this and additional works at: http://soundideas.pugetsound.edu/faculty_pubs

\section{Citation}

Orlin, Eric M. 2007. "Augustan Religion and the Reshaping of Roman Memory." Arethusa 40(1): 73-92.

This Article is brought to you for free and open access by the Faculty Scholarship at Sound Ideas. It has been accepted for inclusion in All Faculty Scholarship by an authorized administrator of Sound Ideas. For more information, please contact soundideas@pugetsound.edu. 


\section{PROJECT MUSE}

\section{Augustan Religion and the Reshaping of Roman Memory}

Eric M. Orlin

Arethusa, Volume 40, Number 1, Winter 2007, pp. 73-92 (Article)

Published by The Johns Hopkins University Press

DOI: 10.1353/are.2007.0004

$\Rightarrow$ For additional information about this article

http://muse.jhu.edu/journals/are/summary/v040/40.1orlin.html 


\title{
AUGUSTAN RELIGION AND THE RESHAPING OF ROMAN MEMORY
}

\author{
ERIC ORLIN
}

I begin this paper with a passage from Book 12 of the Aeneid (834-40):

sermonem Ausonii patrium moresque tenebunt, utque est nomen erit; commixti corpore tantum subsident Teucri. morem ritusque sacrorum adiciam faciamque omnis uno ore Latinos. hinc genus Ausonio mixtum quod sanguine surget, supra homines, supra ire deos pietate uidebis, nec gens ulla tuos aeque celebrabit honores.

The Ausonians will keep their fathers' language and their way of life, and their name will be as it is. The Teucrians, having been mixed only in blood [with the Ausonians], shall settle down. I will add a custom and rites for sacrificial practices, and I will make them all Latins with a single language. From here, you will see that the race that arises mixed with Ausonian blood will surpass men and the gods in piety, nor will any clan celebrate your honors so well. ${ }^{1}$

1 Subsident in line 836 could be taken to mean either (or both) that the Teucrians shall settle down in the land or that the Teucrian name shall sink down into oblivion, presumably as a result of the mixing with the Ausonians as Williams 1973.498 suggests.

All translations are my own. 
This programmatic prophecy of Jupiter toward the end of the poem, reconciling Juno to the fate of Aeneas and his band of Trojans, offers many points worth discussing, but in this paper, I want to focus on the image it offers of the origins of Roman religion. ${ }^{2}$ Although Jupiter promises that the Trojans shall mix their blood with the indigenous inhabitants of Italy, he does not say that the religious practices of the new people will similarly be a mixture of indigenous and Trojan practices. Rather, he promises that he will give the new people morem and ritus of their own, seemingly ex nihilo. This proposition is surprising for two important reasons. First, the history of Roman religion as best we can trace it today is the story of the mixture of a variety of elements from Italy and overseas, and Virgil was well aware of this history, since it is mostly known to us from his contemporary Livy. Secondly, this passage attributes Roman religion to a single divine source, Jupiter, as if it were a divine revelation, despite the fact that up until the Augustan age, and even beyond, the Romans were at pains to minimize the role of prophetic utterances in their religious system, and there are no previous hints that they conceived of their religion as "revealed" or delivered by the gods. Virgil thus offers a profoundly different conception of Roman religion in this passage, one that is at sharp odds with the actual history of Roman practice. This paper will argue that the Augustan religious program reveals the same reconception of Roman religion, and more importantly, that this new model played a vital role in the emperor's efforts to create a unified sense of identity that included both Romans and Italians.

One of the critical problems facing Augustus at the conclusion of the conflict against Antony and Cleopatra was to reestablish a sense of unity amongst the Romans. It must be remembered that the civil wars stretched back not merely to the confrontation between Caesar and Pompey, but to the Social War and the campaigns of Sulla over fifty years prior to Actium, and that these clashes pitted not only Romans against Romans, but also Romans against other inhabitants of Italy. In the wake of the Social War, the boundary between Roman and non-Roman had become distinctly blurred, as Italians had increasingly been admitted to Roman citizenship, though

2 This passage is highlighted by Toll 1991.8 in a paper that sparked my thinking on these issues. 
perhaps not yet to an equal position within the Roman state. The civil wars among Roman politicians, first Sulla and Marius, then Caesar and Pompey, and finally Octavian and Antony, created further problems. Roman fought Roman, and even partisans of the same leader fought against each other. The frequent proscriptions and alternating interdictions of citizens displaying loyalty to one faction or the other exacerbated the situation; possession of citizenship proved no defense against slaughter.

For these reasons, the late republic, as Andrew Wallace-Hadrill (2000.295) observes, is marked "by a collapse of the ability to define physically what being Roman consists in, and the reign of Augustus marks a new coherence of definition." Ever since the publication of Ronald Syme's Roman Revolution (1939), it has been recognized that this new coherence included Italians within its definition; the triumph of Augustus also marked the triumph of the Italian municipalities. Furthering the integration of these communities into the Roman state was one of the main accomplishments of Augustus's reign, nor was this merely an accident or a by-product of other Augustan actions: Augustus prided himself on his support from all Italy, or tota Italia as he says in the Res Gestae ( $R G 25$; cf. $R G$ 10). The construction of a unified sense of cultural identity comprising both Romans and Italians, that is, redefining what it meant to be Roman so as to include the Italians, must rank as one of the signal accomplishments of the Augustan regime. Along with other elements of the Augustan program, religion played a vital role in this process.

The importance of religion to group identity has become increasingly evident in the wake of the events of recent years and has been the focus of work by many social scientists over the past decades. Anthony D. Smith (1986.35-37) singles out several aspects of religion as especially significant for ethnic identity, in particular, the relationship between a community's origin myths and its place in the cosmos and the way in which religion provides channels for the diffusion of myths and symbols that provide group cohesion. These observations can be applied to the Romans, for religion played a critical role in the cohesiveness of their state and formed an important aspect of their identity. Both founder-figures of Rome, Aeneas and Romulus, were born of a divinity, both received special attention from the divine during their lifetimes, and both were divinized upon their deaths. Even Livy (praef.) claims that "if any people ought to be allowed to claim a divine origin and point to the gods as their founders, that people is Rome." The evidence for this claim of special divine favor lay in Rome's superiority in war, and texts both literary and epigraphical from as early as the second 
century B.C.E. reveal that the Romans considered themselves the most religious of all peoples and ascribed their imperial success to this fact. ${ }^{3}$

Of equal interest for the purpose of this paper is the necessity for religious traditions to evolve in order to maintain group identity; in his discussion, Smith (1986.120) notes that "the ability of a religious tradition to renew itself and adapt to different conditions" is a key factor in the persistence and survival of ethnic group identity. ${ }^{4}$ As the composition of the group changes, its religious traditions must change as well or the group may lose one of the primary factors that give it cohesion. As is well known, Augustus devoted tremendous energy and resources to religious reform, beginning in the years immediately following the climactic battle at Actium and continuing all the way through his reign, and the basic outlines of these reforms have been well explored by previous scholars. ${ }^{5}$ I suggest that these reforms need to be considered in the light of both the challenges posed by the civil wars to Roman group identity and Augustus's attempts to bring a new coherence of definition to that issue. The passage from the Aeneid with which I began this paper reveals the fundamentally different lines along which Roman religion was reconceived during the reign of Augustus.

Although the passage suggests that Roman religion stemmed from the actions of a single divine figure, the history of Roman religion, as best it can be read from the pages of Livy and other Roman sources, is one of the gradual accretion of cults and practices from around the Mediterranean. The process began with cities and towns closer to Rome, in Latium, Etruria, and Campania, but extended overseas to include Greece, Asia Minor, and eventually even Egypt, in the form of such cults as Aesculapius, the Magna Mater, and Isis. ${ }^{6}$ The bulk of the evidence for this history comes from the pages of Livy, with their annual record of the foundations of new temples and the inauguration of new religious rituals. While it is possible that some elements of this history may have been idealized and retrojected

3 Cf. Cicero ND 2.3.8, HR 19; Sall. Cat. 12. For an inscription of 189 B.C.E., see IGRRP 4.1557. See Edwards 1996.44-68 for a discussion of the importance of religion to Roman identity, especially in the time of Augustus.

4 Whether or not the Romans can properly be considered an "ethnic" group, the issues of group identity that Smith discusses are clearly relevant to the Roman situation.

5 For earlier studies of Augustus's religious reforms, see Nock 1934, Liebeschuetz 1979.55100, Kienast 1982.185-214, and further bibliography cited there.

6 Beard, North, and Price 1998.61-84 provides a good survey of innovation in Roman religion. 
into the early days of Rome, it is supported in its main outlines by such material remains as we have for Rome during the republic, and it is well attested for the period from the Second Punic War onward, a time when we have more confidence in our literary texts. That Livy is the source for much of this history strongly suggests that his contemporary Virgil was aware of this tradition, and yet in Book 12 of the Aeneid, as we saw at the outset of this paper, he suggests a much different picture, a picture in which Roman religious practice is not attributed to this historical process but stems from a divine source and even dates back prior to the foundation of the city of Rome.

The notion that Roman religion is the result of divine inspiration also runs counter to established practice at Rome. One of the salient features of Roman state religion during the republic is its lack of a prophetic tradition. Unlike in Greece, oracles such as at Delphi were rarely consulted and played a minimal role in decision making by the state, and unlike in ancient Israel, charismatic individuals who claimed divine sanction were not accepted as legitimate sources of authority. ${ }^{7}$ On the contrary, seers or vates were often greeted with skepticism, and occasionally with repression, by the Roman government. ${ }^{8}$ Furthermore, there was no sacred text given by a divine power that might contain revealed "truths" around which a religious system might develop. The nearest counterpart would be the Sibylline Books, yet these contained only prescriptions for how prodigies could be expiated; there seem not to have been prophecies about what would happen in the future, but only ritual actions for how to handle the past, and even then, these books were hedged about with protections to avoid their abuse by individuals. ${ }^{9}$ In this regard, the use of the Sibylline Books conformed to general Roman practice in the face of divination: avoid locating authority, in religious affairs as well as in all other affairs of state, outside of the senate (cf. North 1990).

The Aeneid directly contradicts this tradition. In the grand reconciliation vision of Jupiter, Roman religion is presented as the result of a single divine benefaction: Jupiter promises that he will give a single religious

7 On the difference between Roman divination and Greek oracles, see Liebeschuetz 1979.8 n. 1.

8 Livy 25.1; cf. 25.12. See also Val. Max. 1.3.2.

9 On the Sibylline Books in general, see Parke 1998.136-51. For the controls placed on the use of the Sibylline Books, see Dion. Hal. Ant. Rom. 4.62. 
practice to the new people. The short space of a few lines suffices to reveal that Virgil is presenting a far different set of premises about Roman religion than Roman society had operated with for centuries. ${ }^{10}$ In part, these differences can be ascribed to the changed political situation at Rome, that is, the dominance now exercised by Augustus. Although Augustus would not assume the office of pontifex maximus until 12 B.C.E., the close interrelationship between religion and politics at Rome ensured that he became the dominant figure in the religious sphere at the same time as he became the dominant political figure. As the republican system located authority in the corporate body of the senate, and as religious innovations, such as the addition of new cults, derived from the senate working in concert with individuals, under the empire, all such authority was located in the person of the princeps and religious innovation stemmed from his decisions. The image of Jupiter granting morem ritusque may fairly be likened to the position of Augustus in relation to his own countrymen; certainly in the Secular Games that Augustus staged two years after Virgil's death, the emperor offered both a new custom and a new rite for this ancient festival. The new political reality thus might account in part for Virgil's depiction of divine inspiration for Roman religious practices, but the simultaneous move away from a historically based understanding of those practices points to a further meaning.

I suggest that the key to understanding this dramatic shift lies in the fact that the vision presented in the Aeneid is more conducive to the establishment of a broader Roman identity, open to Italian municipalities as well as to others. The history of Roman religion tied it to a particular people at a particular time and place: different cults had been introduced at recognized times by recognized individual Romans who built temples in easily identifiable parts of the city. Roman religion has been character-

10 O'Hara 1990.130 warns us that "Vergil's point of view cannot simply be equated with Jupiter's" since many of these prophecies are intended to deceive. This is a salutary reminder, though prophecy in the ancient world always has the capacity to deceive; it is the task of the human recipient to correctly interpret the prophecy. The importance of this passage and the shift it represents lies in the fact that Virgil even offers this new vision as a possibility; as Fowler 1990.57 notes: "Merely to show that there are other possibilities is a radical act." Regardless of whether Jupiter expresses Virgil's own vision, the prophecy opens up a new range of possibilities. On the role of Jupiter as a character in the poem whose perspective is difficult for either the narrator or the reader to grasp, but who nonetheless offers a commanding viewpoint, see Feeney 1991.137-55. 
ized as a religion of place, and this is certainly the picture that emerges from Livy's presentation. ${ }^{11}$ Nowhere is this notion expressed better than the speech of Camillus at the end of Book 5 in which he dissuades the Romans from moving to Veii instead of rebuilding the city:

We possess a City that was founded with divine approval as revealed in auguries and auspices; there is no spot in it that is not full of religio and the gods; the festive sacrifices have appointed places no less than they have appointed days ... Perhaps someone might suggest that we can either perform these rites at Veii or send our priests to perform them here. But neither of these things can be done without a violation of the ceremony. Not to enumerate in detail all the rites or all the deities, but in the case of the feast of Jupiter, where else but on the Capitol can the couch of Jupiter be prepared? . . [Our ancestors] left to us certain rites that need to be performed on the Alban Mount or at Lavinium . . . So far we are speaking about the temples and about rites. But what about the priests? Has it not occurred to you what a great sin is being committed? For the Vestals, assuredly, there is only one seat from which nothing has ever moved them except the capture of the city, and it is forbidden for the flamen Dialis to remain a single night outside the city. ${ }^{12}$

This conception of Roman religion is very much a religion of place, of particular rites and ceremonies handed down by Roman ancestors with a

11 On Roman religion as a religion of place, see Beard, North, and Price 1998.167-68.

12 Livy 5.52: "Urbem auspicato inauguratoque conditam habemus; nullus locus in ea non religionum deorumque est plenus; sacrificiis sollemnibus non dies magis stati quam loca sunt in quibus fiant ... Forsitan aliquis dicat aut Veiis ea nos facturos aut huc inde missuros sacerdotes nostros qui faciant; quorum neutrum fieri saluis caerimoniis potest. Et ne omnia generatim sacra omnesque percenseam deos, in Iouis epulo num alibi quam in Capitolio puluinar suscipi potest? . . . Illi sacra quaedam in monte Albano Lauiniique nobis facienda tradiderunt ... . De sacris loquimur et de templis; quid tandem de sacerdotibus? Nonne in mentem uenit quantum piaculi committatur? Vestalibus nempe una illa sedes est, ex qua eas nihil unquam praeterquam urbs capta mouit; flamini Diali noctem unam manere extra urbem nefas est." 
specific history. ${ }^{13}$ This conception is narrow in the sense that Roman religion can only be performed at Rome; it specifically denies the possibility that the same rites could be performed at Veii and still be called Roman, and thus precludes the possibility of other inhabitants of Italy participating in Roman rituals outside the city.

In contrast, the ascription of Roman religion to a time when Rome as a city did not yet exist de-emphasizes the notion of place in Roman religion. The action of the Aeneid takes place when Rome itself does not even exist; Alba Longa has yet to be founded, let alone Rome, so any rites cannot be exclusively tied to monuments on the Capitol or within the pomerium. This point emerges most strongly at the very point where Virgil appears to be focused on Rome as a place, in Book 8, where Evander meets Aeneas at the site that will become Rome. First, Virgil depicts Evander performing a sacrifice in honor of Hercules at the Ara Maxima and recounting the role of the Potitii and Pinarii in these rites (lines 175-305). Subsequently, the Arcadian king takes Aeneas on a tour of the site where Jupiter's temple will be located in Virgil's day (305-69), though Virgil carefully notes that, in those days, the Capitol was still an overgrown thicket (dumis silvestribus). Significantly, although Aeneas can sense the religio of the place, Evander is unable to give a name to the divinity who resides there: quis deus incertum est.

The contrast between Virgil's treatment of the primary Roman deity and the Greek hero is significant. He is willing to provide associations for practices connected with Greek cults, as he does often throughout his poem, perhaps because such practices are not specifically Roman; Greek culture is as much a part of the Italian heritage as the Roman, and more so for some areas of Italy. But Jupiter Capitolinus is inherently linked to the city of Rome; all inhabitants of the Italian peninsula can venerate the religious presence of the Capitoline hill, but identifying that presence as Jupiter Optimus Maximus would narrow that presence to a specific deity identified and worshipped by a particular people at a particular time and place. Virgil's treatment of the pre-Roman Rome and its religious observances undermines notions of those rites as strictly limited to Romans.

13 For further discussion of this point, see Edwards 1996.45-49, Beard, North, and Price 1998.167-81. The speech itself need not represent Livy's own views, though in light of other details throughout the text, it seems likely that it does. On Livy's view of religion, see Levene 1993, who cites (243) "Livy's consistent Romanness" as one of his central conclusions. 
The attribution of the religious practices to Jupiter at the end of the poem also subverts the conception of Roman religion as a historical development connected to a single people. In Virgil's poem, Jupiter grants the morem ritusque sacrorum as much to the indigenous Ausonians as to the Trojans, and he does so, as noted above, at a time when Rome as a city does not even exist yet. This action undercuts the historical traditions surrounding individual rites and cults, and even Aeneas's role in the foundation of Roman religion. Along the same lines, Virgil, in the second half of the poem, appears to de-emphasize Aeneas's task of carrying the Penates safely from Troy to their new home. ${ }^{14}$ The poet thus consciously steers clear of a historical link back to a specific cult in a specific place. Although in the oaths sworn in Book 12 (176-94), Aeneas reminds his listeners that "I will give rites and gods" (sacra deosque dabo), Jupiter's final words in the poem suggest otherwise. ${ }^{15}$ As R. D. Williams (1973.498) notes: "Jupiter here takes responsibility for the mingling with the original Italian tradition of the Trojan worship which was a vital aspect of Aeneas' mission." Jupiter's establishment of the morem ritusque sacrorum avoids specific historical and geographic associations, and by having Jupiter grant new religious practices to the amalgamated Trojans and Ausonians, Virgil implies that all those who inhabit the Italian peninsula and performed these rites might have an equal claim to be performing "Roman" religious rituals. The reader need not assume that the process of amalgamation will be easy, but the poet's suggestion offers an avenue towards creating unity between Roman and Italian. ${ }^{16}$

I began this discussion of the reconception of Roman religion with the literary material since the contrast is most visible in the difference

14 Penates are specifically mentioned by Virgil twenty-five times in the Aeneid; sixteen of these mentions occur in the first five books of the poem, helping to establish Aeneas as pius in fulfilling his obligation to the gods. But as the poem proceeds to Italy, the word appears only eight more times, and only once (in a hostile speech of Turnus at Book 8 , line 9) in a context that reminds the reader that Aeneas has carried them to Italy.

15 Lyne 1987.81-83 sees Jupiter here as merely glossing over a fact that will be unpalatable to Juno, but O'Hara 1990.144 argues that: “Aeneas' words in Book 12, the thematic connotations of Troy and Italy in Books 7-12, and the Rome that Vergil knew, create the strong impression that Jupiter's words to Juno are true."

16 For this argument, it is not necessary to choose between the optimistic and pessimistic readings of the Aeneid, for either can be applied to Jupiter's prophecy. Cf. O'Hara 1990.132: "Vergil is concerned with and sympathetic to both the optimism and hope that the surface of the prophecies most eloquently presents, and the nagging fear and pessimism discernible in the depth of the prophecy scenes and elsewhere." 
between the texts of Virgil and Livy, but the religious program of Augustus reflects the same reconception of Roman religion as seen in Virgil. On this point, as on others, poet and princeps shared a similar view, though naturally the emperor's vision appears in a different medium and from a different perspective. Augustus's reconception may perhaps be seen most clearly in one of the most cited elements of his religious program: the restoration of temples throughout the city of Rome. In the Res Gestae, Augustus wrote: "Consul for the sixth time (28 B.C.E.), I rebuilt eighty-two temples of the gods in the city by the authority of the senate, omitting nothing that ought to have been rebuilt at that time." ${ }^{17}$ It is highly unlikely that the restoration of all eighty-two temples was completed in a single year, though that is sometimes the impression one gets in reading about the Augustan restoration. A more realistic interpretation is that Augustus began work, with much fanfare no doubt, on the eighty-two temples at this time, which would still be a remarkable accomplishment and statement of his intentions in regard to Roman religion. ${ }^{18}$ Just the program of restoring temples would have had a profound impact on Rome and Roman identity, but we will see that the significance of the Augustan program runs deeper than this.

Roman temples served not only as religious sites, but also as historical monuments. Temples were vowed during the republic at specific historical moments, usually during the course of a battle or other crisis affecting the state, and often bore inscriptions that indicated the man who had vowed the temple and under what circumstances. ${ }^{19}$ The temple of Lares Permarini, dedicated in 179 B.C.E., provides a good example. Livy recorded an inscription affixed to the temple that indicated the temple was vowed by Lucius Aemilius in consequence of the naval battle that he fought against King Antiochus between Ephesus, Samos, and Chios; the inscription further noted that the battle took place under the very eyes of Antiochus, his cavalry, and his elephants, and that forty-two of his ships were captured, complete with

$17 R G$ 20: "Duo et octoginta templa deum in urbe consul sextum ex auctoritate senatus refeci nullo praetermisso quod eo tempore refici debebat."

18 Cf. Gros 1976.15-18 on Augustus's claims in the Res Gestae. Gros comments on Augustus's curious remark about omitting nothing that was worthy to be rebuilt, ascribing this not only to satisfaction but also to a sense of fulfilling religio in Roman terms, that Roman success depended on proper cultivation of the gods. But the phrase is also suggestive of Augustus's power over Roman religion; the princeps is now the arbiter of what is worthy of rebuilding, implying that any temples not rebuilt were not worthy of it.

19 On the founding of new temples in Rome, see Orlin 1997. 
their crews. ${ }^{20}$ Roman temples, then, served not only as the loci for ritual activity in providing places for Roman religion, but also as monuments in which Roman memories and Roman history resided. In this dual role, it is easy to understand Livy's attention to them, not only on account of his conception of Roman religion as a religion of place, but because of their indispensable role in shaping Roman identity. Mary Jaeger in her book on Livy calls attention to Varro's definition of a monumentum and the ways in which such monuments shape Roman memory and thus Roman identity (1997.18): "The monumentum controls and directs the viewer's thoughts as they move from the present to the past, then back to the present and into the future." ${ }^{21}$ As viewers encounter a temple, their attention is drawn to the specific person who built the temple and the specific event it commemorates, and are thus reminded of the accomplishments of their ancestors and of what it means to be Roman.

This discussion has direct relevance to the temples rebuilt by Augustus, for a temple that is reconstructed recalls a different past, that of the reconstruction, as much as that of the original structure, and in so doing, calls attention to a different present and a different future. This is true even if the temple continued to carry the words of the original inscription. On the best-known example, the Pantheon, the Hadrianic rebuilding ostentatiously retained the original inscription of Aprippa, drawing further attention to Hadrian for piety and humility in preserving the name of the temple's original founder. Augustus's decision not to attach his name to other monuments he rebuilt, such as the Theater of Pompey and the Portico of Octavius ( $R G$ 19-20), indicates that he was well aware how this game was played. While Walter Eder (1990.84) rightly cautions about crediting images with too much power to create new identities because even new images depend on references to the past, this very point makes the reconstructed temples

20 Livy 40.52: "Duello magno dirimendo, regibus subigendis, caput patrandae pacis causa haec pugna exeunti L. Aemilio M. Aemilii filio *** Auspicio imperio felicitate ductuque eius inter Ephesum Samum Chiumque, inspectante eopse Antiocho, exercitu omni, equitatu elephantisque, classis regis Antiochi antehac inuicta fusa contusa fugataque est, ibique eo die naues longae cum omnibus sociis captae quadraginta duae. Ea pugna pugnata rex Antiochus regnumque ***. Eius rei ergo aedem Laribus permarinis uouit."

21 Cf. Varro $L L 6.49$ : "From the same word comes monere, 'remind,' because he who reminds is just like memory . . . things that are written or made for the sake of memory are called monumenta, 'reminders.'" For further discussion of the links between history and identity, see the essays collected in Gillis 1994. 
so potent, for the new temples call attention precisely to a new past. A viewer did not need to know the history of the original building, only the new building reconstructed by Augustus. In rebuilding these temples, and especially by working on so many structures at once, Augustus began to reshape Roman memory and, in the process, he put forward a new conception of what it meant to be Roman. There is no doubt that, in part, this conception revolved around the central place of the emperor in the Roman state, but it was also intended to include those who had not originally been a part of the Roman state, as a closer examination of the reconstruction program reveals.

Pierre Gros, in his study of the religious architecture of Rome under Augustus, notes a curious fact about the reconstructions: the first temples rebuilt were not always those that would seem to be most important, but rather those, such as Jupiter Feretrius, Victoria, and Saturn, whose antiquity made it possible to associate them with Rome's remote past (1976.26). The latter two cults were linked to Evander and Hercules, and thus these temples were connected as much with pre-Roman Italy as with the specific city of Rome. ${ }^{22}$ By evoking this era with the first temples to be rebuilt in Rome, Augustus harkened back, just as Virgil had done, to a time when there were no specifically Roman connections to these temples-as noted above, Rome did not yet exist. ${ }^{23}$ On the other hand, the temple of Castor and Pollux was not rededicated until 6 c.E., although it had been built in the very first decade of the republic. This temple, constructed as a result of

22 While the temple of Jupiter Feretrius was supposedly built after the founding of Rome, Romulus in a sense is a "pre-Roman" as well, and his acceptance of foreigners into his new city, via the asylum for instance, makes him a similar figure to Evander and Hercules in suggesting connections beyond the immediate city of Rome. See further the discussion in Gros 1976.128.

23 In addition to dating from Rome's deep past, Evander and Hercules are Greek heroes and so also point to Augustus's acknowledgement of the Greek influence upon Roman religion. The impact of Greek practices on Roman religion and Augustus's relationship to Greek culture are topics far too large to be treated in this paper. I would only suggest that an emphasis on the Greek connections of certain Roman cults and practices is entirely in keeping with Augustus's aim of emphasizing elements that are not narrowly tied to Rome but might be related more broadly to the inhabitants of Italy. It is worth noting that Virgil devotes significant space in Book 8 (184-369) to stories of religious practice involving Hercules and Evander, displaying a similar interest in the Greek heroes of ancient (i.e., pre-Roman) Italy. On the reception of Greek cults in Rome as seen in literary sources, including Virgil, see Cancik 1999; on Greek influence on Roman religious practice, see Beard, North, and Price 1998 passim. 
the victory of the Romans over the Latins at Lake Regillus, had associations that Augustus may not have wished to emphasize in this context. The priority that Augustus placed on restoring temples that might be associated with the pre-Roman heroes of Italy directs attention to the importance of cults that could belong equally to all who inhabited the peninsula of Italy.

The numerous stone fasti dating from the early empire reveal a similar interest in the remote past and thus make a similar contribution to reshaping Roman memory and identity. Certainly these calendars evince a focus on dates of importance to Augustus and the imperial family, and the placing of Augustus on the republican festival calendar, as Wallace-Hadrill (1987.226) phrases it, "inserts Augustus into the heart of this way of representing what it means to be Roman." ${ }^{24}$ While celebrating Augustus's role in the state was part of the current identity of any Roman, Wallace-Hadrill also observes that the festivals on the fasti tend to cluster either toward the Augustan or the Romulan eras, with only a scattering from the period between those two poles. Again the attempt to link up the present to the "deep" origins of the Roman past is clearly discernable. As I suggested in reference to the temples that offered a connection to the remote past, this period was attractive to Augustus not because it was "uniquely and unchallengably Roman" in Wallace-Hadrill's words, but because, in the time of Romulus, there was not yet a narrowly defined sense of what it meant to be Roman. It was Romulus who had created the asylum on the Capitoline to attract new strength to Rome, Romulus who had made the alliance with Titus Tatius to incorporate the Sabines into the Roman state, and, after the death of Romulus, Numa, a non-Roman, had even been chosen as king. ${ }^{25}$ In the time of Romulus, Italians played a role every bit as important as Romans in building the Roman state and Roman identity, and I suggest that Romulus was so appealing to Augustus as a model not merely as a founder-figure, but out of recognition of this factor. The rewriting of the calendar thus contributes significantly to a rewriting of memory, pushing the expansionist history of Rome (often at the expense of Italians) to the background and placing Romulus and Augustus, and their embrace of surrounding Italy, in the forefront of an observer's consciousness.

24 On the significance of the calendar for what it means to be Roman, see Beard 1987. On the changes to the festival calendar under Augustus, see also Fraschetti 1990.9-41.

25 For these stories, see Livy 1.6-8, 1.13, and 1.18. 
The fasti reveal another way in which the rebuilding of temples by Augustus contributed to the reconception of Roman religion and the reshaping of Roman identity. According to the dates preserved on these stone calendars, at least fourteen of the restored temples were rededicated on a different day from their original dedication day; that is, the dies natalis on which festivals at the temple were celebrated moved to a new day. ${ }^{26}$ Shifting the dies natalis of a temple that had just been rebuilt or restored contributed significantly to changing the place of that cult in Roman religion. Since the restored temple had a different appearance and, in the future, would have its festivities celebrated on a different day than the original temple, there would no longer be any tangible links to the temple that had existed prior to the Augustan restoration.

This effacement of the prior history of the cult in Rome constitutes a further step in the reconception of the religion of Rome, as can easily be seen by returning to the speech of Camillus from Livy quoted above. In his presentation of Roman religion as a religion of place, Camillus asserted that Roman festivities had their appointed days (dies stati) as well as their appointed places. Augustus's decision to change the established times of Roman religion by moving the dies natalis of a temple thus parallels his decision to de-emphasize the specific places of Roman religion. The festivities held annually at the restored temple would have underlined the disavowal of the temple's prior history in Rome; rather than recalling the temple's original foundation in Rome, the rites served as a reminder only of the temple's refoundation under Augustus. These temples thus insist upon a willful forgetfulness of the prior history of the temple, and this forgetfulness of the past may be an essential ingredient in the construction of a new Roman identity. As John Gillis (1994.7) remarks: "National memory is shared by people who have never seen or heard of each other, yet who regard themselves as having a common history. They are bound together

26 See Gros 1976.31-36. Gros notes that many of these alterations in the calendar served to focus attention on the imperial family, for they involved significant dates in the life of Augustus; for instance, six temples were rededicated on the 23rd of September, which conveniently happened to be Augustus's own birthday. New temples were similarly dedicated on days important to Augustus: the grand temple of Mars Ultor in the Forum of Augustus was dedicated on August 1, the anniversary of Augustus's entry into Alexandria, while the temple of Concordia was dedicated (by Tiberius, after the death of Augustus) on January 16, the day on which the name "Augustus" had been bestowed on the princeps. Cf. below, p. 87. 
as much by forgetting as by remembering." ${ }^{27}$ Reshaping past memories is a key stage in the creation of a new present, and thus a new future, for the Roman state. The reordering of Roman topographical and chronological space has profound implications for the reshaping of Roman memory and Roman identity, linked not to the history of expansionist Rome over the previous 500 years, but rather to Augustan Rome and its fuller inclusion of Italy.

The surviving evidence allows us to see this process most clearly with the restoration of the temple of Concord. This temple, with its dies natalis on July 22, was said to have been erected originally by Camillus in 367 following the passage of the Licinian laws, and was restored by the consul L. Opimius following the death of C. Gracchus in 121, in a move clearly designed to throw the weight of the senate against the emerging populist politicians. ${ }^{28}$ Augustus delegated the rebuilding of this temple to Tiberius, who used his spoils from Germany and rededicated the temple to Concordia Augusta on January 16, 10 C.E. The renaming of this temple makes the effacement of the original even more evident. Whereas the original temple recalled the supposed concord that followed two incidents of civil strife in Rome, the Tiberian temple called to mind the Augustan peace, and its dies natalis celebrated the date in 27 B.C.E. on which the princeps had received the name Augustus. The restored temple thus conveyed an entirely different set of meanings than did the original temple, tied as it was now to the Augustan regime as if the earlier temple had never existed and available to those who partook of the Augustan concord; indeed, the new concord between Italy and Rome may be seen as an important part of the concordia Augusta. ${ }^{29}$

27 John Henderson 2000.1-26 suggests that another Roman example of such intentional forgetting may be at play in Virgil's occlusion of the town of Ardea in the Aeneid-another example of how the themes of the poem and the Augustan religious restoration are intertwined.

28 Momigliano 1942 doubted that the Camillan temple was built, suspecting that the story of its construction was part of the later Camillus legend. The Opimian temple is attested by numerous authors, including Cicero (Sest. 140), Appian (BC 1.26), and Plutarch (C. Gracchus 17).

29 Another example of Augustus's rewriting Roman memories through temple reconstruction is provided by his treatment of the temples of the circus Flaminius. This locale had been a favored spot for temples constructed by victorious generals of the second century B.C.E., but Augustus revamped the entire area, replacing the porticus Metelli with the porticus Octaviae and restoring temples of Juno Regina, Jupiter Stator, Mars, Apollo, and Neptune. All five temples were rededicated on the 23rd of September (possibly in different years). 
These types of changes did not affect every temple in Rome, for Augustus did not change the dies natalis for every temple restored as part of his religious program, and many continued to celebrate their rites just as they had during the republic. This fact should not be surprising, for the Augustan program depended for its success on maintaining a proper balance between change and continuity, and Augustus regularly presented his innovations as a return to older traditions rather than as revolutionary reconceptions. Gary Miles (1988.204-08) suggests that certain institutions may have been central enough to Roman identity that to change them would threaten, rather than strengthen, that identity, and this notion is borne out by several of the temples whose dies natales remained unchanged. The temple of Jupiter Optimus Maximus on the Capitoline hill retained its dies natalis of September 13, and the temple to Ceres, Liber, and Libera, which had been a center of plebeian activity for many years, continued its celebrations on the 19th of April. It may be that the ludi connected with these two cults, the ludi Romani and the Cerealia respectively, inhibited the movement of the dies natales of these temples, but those festivities simply emphasize the point that some temples were too tightly bound up in the religious life of Rome to be moved around the calendar. Augustus's efforts were not directed at erasing Roman identity but at reshaping it, and that identity remained recognizably Roman even as it became more accessible to those living outside the city of Rome itself.

Augustus's reforms, therefore, did not aim to displace Rome as the center of Roman religion, but to "re-place" Roman religion in the city. ${ }^{30}$ Physically this can be seen in the restoration of the eighty-two temples, all located in the city of Rome. The importance of place flows naturally from Augustus's charges against Antony during their propaganda war that the latter desired to move the capital from Rome to Alexandria, while Augustus had the support of tota Italia ( $R G 25)$. The emphasis on place in Livy's presentation of Camillus is therefore not anathema to the Augustan program; even Virgil, in the passage from Book 8 discussed above, recognized the

The new visual appearance of these five temples, along with the portico, and the new date for the celebrations held in this area thus replaced the memories of the conquering generals of Roman history with images of the triumphant Augustan regime.

30 The phrase is borrowed from Beard, North, and Price 1998.181-210. Edwards 1996.45-52 also uses this phrase as a subheading for her analysis of Livy's treatment of the speech of Camillus. 
importance of place. ${ }^{31}$ I suggest, however, that the significance of Camillus as a model for Augustus lies not in his insistence on maintaining the specific rites attached to archaic Rome, but in his refoundation of the city after it had been threatened with extinction. Gary Miles (1986.2) proposes that, through his presentation, Livy suggests "the possibility that Roman identity and greatness may be preserved indefinitely through successive reenactments of a historical cycle." It is this fact of refoundation that sets Camillus and Augustus apart from others named as conditores by Livy, as these two figures reaffirm essential Roman principles and thus ensure the continuity from one cycle to the next. ${ }^{32}$ The story of Camillus throughout Book 5 implies that a refoundation cannot simply recreate the past, but must incorporate certain elements and then continue forward in order to successfully provide the needed continuity. ${ }^{33}$ The close of the book is suggestive; while the report of the haphazard rebuilding of the city might appear to be an anticlimax, it is an essential link that proceeds forward and provides a beginning for the new cycle of Roman history. ${ }^{34}$ An astute audience would undoubtedly think of the Augustan rebuilding program; by re-placing Roman religion within the city while moving beyond a narrow conception of Romanness, Augustus offered a refoundation to preserve Roman greatness and identity for the future.

One may naturally ask how widespread the impact of the Augustan religious program would have been, considering the limited distribution of the surviving fasti both in time and space..$^{35}$ The geographical limitation may be particularly relevant, as the ceremonies now being celebrated on different days would have been held at temples in Rome, and the reconstructed temples themselves were, of course, located in Rome. These last two factors may, in fact, hint at the principal audience for these religious

31 Book 8.305-69; cf. above, p. 80.

32 Miles 1988.199-200. Note that Augustus is identified by Livy as the "templorum omnium conditorem et restitutorem" ("founder and restorer of all temples," 4.20), a clear reference to the reconstruction of the eighty-two temples that are under discussion here. Camillus is described more broadly as "Romulus ac parens patriae, conditorque alter urbis" ("Romulus and the father of his country, a second founder of the city," 5.49.7), a phrase that also has clear resonances with Augustus.

33 See Kraus 1994a, esp. 278-82, on the importance for Roman identity of moving beyond a simple repetition of the past.

34 On this closing passage, see Kraus 1994a.285-86.

35 I am grateful to Andrew Riggsby for raising this question in his response to the paper and in a subsequent email exchange. 
reforms. W. Eder (1990.87) suggests that the Augustan ideological program was directed primarily at the senatorial ruling class, though naturally it affected other groups as well, and I suggest that this is particularly true of the religious component of that program. ${ }^{36}$ For the senatorial elite, who over the past hundred years had repeatedly shown themselves disinclined to recognize the other inhabitants of Italy on an equal footing, the rewritten history of Rome's religious past served notice of the emperor's intent to treat Italians as equals from this point forward. The reconstructed temples would have been evident to Roman senators as they moved about the city and participated in the business of the city, including its religious rituals, and some members of the elite had even, on the prompting of Augustus, paid for some reconstruction work themselves. ${ }^{37}$ Those senators who were members of the college of pontiffs, which had previously held responsibility for the calendar in Rome, would have been the best positioned to understand the significance of the changes to the fasti, and members of the other religious colleges would similarly have been able to understand the nuances of Augustus's religious activity. The message may have been less evident to the Italians, but may also have been less important to them, as they were affected in more material ways, such as the extension of legal and political privileges and the safeguarding of private property. Nonetheless, it provided an important symbol of their place in the Augustan regime.

Some hints as to how far Augustus was successful can be seen already in the first century C.E., in the famous debate during the reign of Claudius over allowing the Aedui into the senate. ${ }^{38}$ Claudius's speech, as recounted both on the Lyons tablet (ILS 212) and in the account of Tacitus (Annals 11.23-34), touches on many familiar themes concerning the habitual openness of the Roman state: noble families such as the Julii and the Porcii originated from cities other than Rome, foreigners on the throne of Rome,

36 Eder at the bottom of page 87 also remarks on the importance of identity and a new history under Augustus: "Thus personal pride in the fatherland, in particular a feeling of 'we-ness,' was encouraged, which permitted each Roman to find his own place as a civis Romanus and as a part of the history of the Roman state." Since Roman citizenship had been extended to Italy by this time, we might as easily say that each Italian was permitted to find his own place in the state and in Roman history.

37 Suetonius (Aug. 29) reports that Marcius Philippus rebuilt the temple of Hercules and the Muses, Munatius Plancus rebuilt the temple of Saturn, and Lucius Cornificius rebuilt the temple to Diana. An inscription confirms the rebuilding of the latter temple, identifying it as Diana Cornificiana; cf. CIL 6.4305.

38 On this debate and its significance for identity issues, see Giardina 1997.3-10. 
and, of course, various actions of Romulus. However, what is remarkable in this incident is a line from the Lyons tablet in which Claudius recounts an argument apparently put forward by the senatorial opponents of his policy: "You ask me: is not an Italian senator preferable to a provincial?" The opposition to Claudius apparently argued that Italy was quite capable of providing new members for the senate and that an extension of this privilege would dilute this honor. In doing so, these arguments take the notion of Italy as a full partner with Rome as a given, treating Rome and Italy as a unit in contrast to the Gauls. ${ }^{39}$ Without overstating the significance of this one highly rhetorical incident, it does mark a continued shift in the perceptions of Italians as part of the Roman state.

An excerpt from Pliny the Elder confirms both that the conception of Romanness has shifted and that it is still fundamentally a Roman identity despite its greater inclusiveness. In his discussion of the physical geography of Italy, Pliny ( $N H$ 3.42) rhapsodizes about its forests, fields, and then remarks: "And I am not here recounting the natural character and the rites, the men, and the nations that have been conquered by its language and its military might?"40 Significantly, Pliny is envisioning a single people, linked by ingenium, ritus, and lingua, inhabiting the peninsula of Italy. For the purposes of this paper, it is surely significant that he singles out ritus as one of the factors identifying this people; the effect of the Augustan program may be seen clearly here. And yet while Italians are fully subsumed within this identity, the identity under consideration is still Roman. Pliny's assertion several paragraphs earlier $(N H 3.39)$ that this land was chosen "to make heaven itself more glorious, to unite scattered empires, and to soften rites" bears more than a passing resemblance to Virgil's charge for the Roman state in the Aeneid (6.852-53; see also the passage cited at the top of this paper). Despite considerable revision to Roman memory, it was not a question of dissolving Roman identity in favor of a pan-Italian identity. Rather, it was necessary to create a new Roman identity that could include residents of the Italian peninsula who lived outside of Rome.

Through his reconfiguration of the religious system of Rome, Augustus simultaneously reconfigured both the physical city and the city's

39 Giardina 1997.18 notes that the senatorial position here is based on a notional consanguinity between Romans and Italians (and, by the end of the debate, also the Aedui), a position that actually differs from that put forward by the Aeneid.

40 On this passage, see Giardina 1997.42. 
past. In the republic, temples had served to chart the growth of Rome and mark specific historical moments or battles won by various generals; they were monuments of memory. In his restoration and rededication of temples, Augustus rewrote that history and presented an image of Roman religion similar to that of Virgil. In this conception, Roman religious practices were not the product of a centuries-long historical development, but of the pronouncements of a single, all-powerful entity that aimed to create a religious system that could be shared by more than one people. Both of the revolutionary concepts hinted at by Virgil thus find expression in the Augustan religious program. Just as Jupiter symbolically founded Roman religion in the Aeneid, so Augustus founded a new religious system that expanded the boundaries of Romanness. The use of divine inspiration as a source for these religious practices, once seen as threatening but now offering an apt expression of the power of the emperor, provides simply another reminder of the revolutionary changes wrought by Augustus on the Roman political and cultural system.

University of Puget Sound 